\title{
COMPUTATIONAL BIOLOGY TOOLS IN DESIGN OF AN AGROCHEMICAL AGAINST Xyllela fastidiosa
}

Stephanie F. Fulaz (IC), Flávia Cabrini (IC), Ljubica Tasic (PQ), Luiz Borro (PG), Goran Neshich (PQ).

\begin{abstract}
Xylella fastidiosa is a Gram-negative, non-flagellated bacterium that causes CVC in citrus and Pierce's disease in grapevines. The CVC affects $40 \%$ of the 200 million orange trees in São Paulo state. It colonizes the xylem vessels of the plants, blocking the water and nutrient flows. PilT protein is a part of the motility system and very important for Xyllela pathogenicity and our protein target for drug design. Computational biology tools were used to design the compound able to inhibit the formation of the PilT hexamer, leading to loss of Xyllela pathogenicity. This approach could be employed in the development of new inhibitors against different targets belonging to the same protein family of PilT.
\end{abstract}

Key words: Xylella fastidiosa, PilT, computational biology tools.

\section{Introduction}

Type IV pili has an important role in the pathogenicity of almost all Gram-negative bacteria, as it is responsible for the motility and bacterial dispersion at surfaces, auto aggregation and biofilm formation. Commonly, the energy required for this movement is provided by ATP hydrolysis which is obtained by PilB and/or PilT protein activities. The inhibition of PilT protein leads to the loss of pathogenicity in some bacteria strains.

\section{Results and Discussion}

Computational biology tools were used to design a homology model for the Xylella fastidiosa PilT protein using the PilT from Pseudomonas aeruginosa and Aquifex aeolicus (PDB entries: 3JVU and 2GSZ). Model refinement and molecular dynamics simulations were used in the model validation procedure. Different pockets in the protein PilT hexamer were identified and used for ligand docking and virtual high throughput screening (vHTS) with commercial compounds. The best inhibitor structures were then improved using de novo compound design techniques aimed to find the best proteinligand pair for posterior in vitro tests.
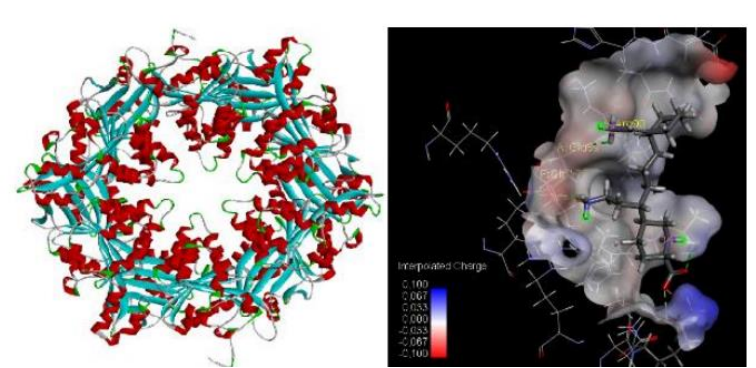

Figure 1. PilT hexamer modeled using $P$. aeruginosa (PDB entry 3JVU) and one pocket with the proposed inhibitor.

\section{Conclusions}

The design of new drugs and agrochemicals could be improved using in silico approach, allowing the discovery of the best sites in the target protein and enabling the design of appropriate inhibitors, providing the best host-inhibitor interaction.

\section{Acknowledgement}

We thank the Embrapa and the Chemical Biology (LQB) research group for their contribution to the inhibitor analysis.

\footnotetext{
${ }^{1}$ Hopkins, D.L.; Purcell, A.H., Plant Dis. 2002, 86, 1056.

${ }^{2}$ Hopkins, D.L., Annu. Rev. Phytopathol., 27, 271-290, 1989.

${ }^{3}$ Neshich, I. A. P.; Nishimura, L.; Moraes, F. R.; Salim, J. A.; Villalta-Romero, F.; Borro, L.; Yano, I. H.; Mazoni, I.; Tasic, L.; Jardine, J. G.; Neshich, G., Curr. Protein Pept. Sci. 2015, 16, 1.

4 EMBRAPA Informática Agropecuária. Neshich, I. A. P.; Nishimura, L.; Salim, J. A.; Mazoni, I.; Jardine, J. G.; Neshich, G. PI1089068 out 2010, Brasil.
} 